\section{Moving in a Circle}

I HAD to cross a very large fhat field in Lincolnshire one even. ing; the ground covered with snow, and there bing a dense fog. I knew my way perfectly ; but on coming to the hedge found that I had deviated to the right. Next day I had occasion to re-visit my tra:k anl found that $I$ had described about one quarter of a ci:cle.

T. M. IV.

\section{FUSTUS LIEBIG}

TUSTUS LIEBIG was born at Darmstadt, the native place of many eminent chemists, May $13,1 \mathrm{So}_{3}$; died at Munich, April 18, 1873.

$\Lambda$ generations pass away, and the deeds and capacities of great men come to be truly estimated, it will be found that the name of Liebig claims a position very cluse to those of Lavoisier and Dalton, the greatest leaders in our science. It is not as the author of the 317 investigations the titles of which fill the pages of the Royal Society catalogue, nor even as the father of organic chemistry, nor as the great originator of a scientific physiolozy and agriculture, nor again as the writer of numerous handbooks, that Liebig has done most for science ; his greatest influence has been a personal one, for it is to him that most chemists now living either directly or indirectly owe their scientific existence. The Giessen Laboratory was the first one in which our science was truly taught, and from this centre the flame of original research was carried throughont all lands by ardent disciples who more or less successfully continuej, bo:h as regards tuition and investigation, their master's work.

Liebig early showed his love for experimental inquiry, and his father apprenticed him-as was then usual in the case of boys who exhibit such tastes-to an apothecary. Ten months of the shop drudgery was sufficient to convince the boy that this sort of life was not what he required, and it is said that he ran away from his pillmaking; at any rate, he returned to his home in Darmstadt, and soon entered the University of Bonn, and afterwards that of Erlangen, where he met with congenial spirits, and continued his scientific education. At that time (1822), bowever, the German universities were almost destitute of means of stimulating research, or even of imparting a knowledge of existing science in its higher and more modern forms; and for this reason the steps of all young German chemists were naturally turned towards Paris, where Gay Lussac, Thenard, Dulong, and other well-known masters were working and teaching. In I822, being nineteen years of age, Liebig had already made himself known in his native town and to its paternal government by the investigation of the action of alkalies on fulminating silver, as well as by other publications on the composition of rertain colouring materials; and the Grand Duke, anxious to promote the glory of his capital, gave his promising young townsman the means of studying in Paris. 'There Liebig, thanks to the friendly introduction of Alexander von Humboldt, was allowed to work in Gay Lussac's private laboratory, where he completed his investigation on fulminic acid, and became acquainted with Gay Lussac's methods of exact investigation. In Paris, too, he met Mitscherlich and Gustav Rose, and the intercourse with them and otlier men of science which he there enjoyed confirmed him in the choice of his profession, and in $\mathrm{IS}_{24}$ he returned home and was appointed, when twenty-one years of age, Extraordinary, and two years afterwards the Ordinary Professor of Chemistry at Giessen, the University of his country, and the scene of the great labours and triumphs of his life.

The influence which Liebig has exerted on the progress of discovery in our science is due to his possession of that peculiar gift essential to all great investigators of nature, which unites to indomitable perseverance in fol- lowing out experimental details, the higher power of generalisation. His indefatigable energy in experimental investigation must be known to all who have even turned over the pages of his Annalen ; there is scarcely a volume $i_{1}$ the thirty years dating from the commencement of the juurnal in 1832 to 1862 , which does not contain some important record of his labours, and in the height of his power the number of independent researches which he was able to carry out at once is certainly marvellous. A mere list of even the most important of his investigations in the one branch of organic chemistry would be far too long for a brief notice such as this; it may, however, be well to call to mind his productivity during the first few years of the Giessen career. In the first rank amongst his earlier researches; and serving as a necessary basis for the whole, come those in which he placed the analysis of organic substances upon a firm and simple basis. His final description of the apparatus is worth remembering-" There is nothing new in this arrangement but its simplicity and perfect reliability." The attack on this subject, commenced in conjunction with Gay Lussac in 1823 , was not completed by himself till 1830; but then he furnished chemists with the simple and effectual methods which, with slight modifications, we still employ. Thus armed, the secrets of the composition of the organic acids and alkaloids were soon revealed, and among the most important discoveries we have first amongst the acids, fulminic (I822), cyanic (1827), hippuric (I829), malic, quinic, rocellic and camphoric (I 830 ), lactic (I 832 ), aspartic (1833), uric (1834), then we find chloral and chloroform (183I), acetal (1832), aldehyde (1835).

In 1837 he published, in conjunction with Dumas, a paper, "Note sur la constitution de quelques acides," in which for the first time the thcory of polybasic organic acids was put forward. Graham's researches on the phosphates proving the polybasic character of phosphoric acid having been published in 1833 . In a research on the constitution of these boties published in $\mathrm{I}_{3} 8$ this was more fully worked out, and Davy's previously expressed views as to the part played by hydrogen confirmed and supported. His researches on the cyanogen derivatives (1834), on the chlorine substitution-producis of alcohol (I832), and those carried on for so many ycars in conjunction with his life-long friend Wöhler, as on the composition of sulphovinic acid (1832), and especially that on the derivatives of benzoic acid ( 1832 ) sufficed to place the theory of organic radicals on a firm basis. Then too we must not forget their conjoint researches, chiefly carried on by correspondence between Giessen and Göttingen on the oxiacids of cyanosen ( 1830 ), a most difficult subject worked out in a masterly way, or that on the formation of benzoyl hydride from amygdalin in the bitter almond (1837), or again the memorable investigations on the nature of uric acid and the products of oxidation of this substance by nitric acid (1838), in which not only a large number of new bodies are described and allantoin artificially pre. pared, but system and order introjuced among the whole.

One of his favourite subjects was that of Fermentation, and his explanation of the phenomena as being due to the action of a substance whose molecules are in a state of motion upon the fermentable body is yet well known, though now in the minds of most supplanted by the germ theory of Pasteur.

As a critic Liebig was sharp, satirical, and sometimes even unsparing and bitter, especially when his own views were assailed; his anonymous critiques are brimfull of good-humoured satire, whilst in others to which he gives his name, he lashes his victim most unmercifully. Who can read his " Das enträthselte Geheimniss der geistigen Gahrung "Vorläufig briefliche Mittheilung," 1839, without amusement? His description of the minute organisms having the form of a Beindorfschen Destillirblase (ohne den Kïhlapparat) feeding on sugar and excreting alcohol 
(aus ein rosenroth gefarbten punkt), and carbonic acid (aus dem Harnorganen) will be long remembered, and even at the present day the satirc has not lost its applicability. Then again in a letter purporting to be written from Paris and signed S. C. H. Windler, though doubtless written by Liebig, he laughs to scorn the idea that the theory of substitution, which he himself upheld, could be so far extended as was by some chemists believed possible. In this letter he states, as the last great discovery of the French capital, that it had been found possible to replace in acetate of manganese, first the atoms of hydrogen by chlorine, then the atoms of oxygen, then those of manganese, and lastly that even the atoms of carbon had been replaced by this gas. So that a body was in the end obtained, which, although it contained nothing but chlorine, still possessed the essential properties of the original acetate of manganese. He adds in a note: "Je viens d'apprendre qu'il y a déjà dans les magasins à Londres des étoffes en chlor filé, très recherchés, dans les hôpitaux, et preférés à tout autres pour bonnets de nuits, calecons, etc.!"

Those who wish to read an unsparing critique, may turn to Liebig's remarks on Gerhardt (I846), to those on Mulder as regards his protein theory, or again on Gruber and Sprengel respecting a review of his own book on Organic Chemistry (1841). It was not in Liebig's nature to spare either private persons or Governments when he thought that science would be advanced by plain speaking. In his two papers on "Der Zustand der Chemie in Oestreich" (1838), and in "Preussen" (1840), whilst he points out the shortcomings of both countries, bravely asserts, in the strongest terms, the dependence of national prosperity upon original research, a subject concerning which in England, most people, thirty years later (to our shame be it said) are altogether in the dark!

Other and wider questions, to the solution of which liebig in later life turned his energies, were those respecting the establishment of a Scientific Agriculture, and the foundation of a new science of Physiological Chemistry. It is in this direction that his labours are best known to the general public in England; and there is no doubt, although in many details his views have since proved erroneous, that he was correct in the main issues, and that the stimulus given to British agriculture through Liebig's writing and investigations, has been of the most important kind. Agriculturists have thus been made aware that a scientific basis for their practice exists which, if not as yet complete, can still explain much in their art of what had previously depended on mere empiricism. Then, again, the interest and attention which were thus brought to bear on these subjects, has led to the establishment of Agricultural Colleges and "Versuchs-Stationen," and to the carrying out of researches like those magnificent ones of Lawes and Gilbert, from which we are receiving information concerning the various questions relating to plant life such as long-continued investigation and observation alone can yicld.

In the year 1852, having lectured for sixty semestres in Giessen, he left the university to which he had given a world-wide fame, to become the centre of a galaxy of men of science whom Maximilian II. of Bavaria had called to Munich. There, having built himself a good laboratory and a spacious house adjoining, he spent the remainder of his days in quiet labour and well-earned and honoured repose. The active period of his life having passed, he entirely withdrew from discussions on purely theoretical questions, and occupied himself with investigations chiefly of a practical character, such as those on the extract of meat, and on infants' food. He continued to re-edit his various books, indulging occasionally in his old habit of a sharp hit at the views of some scientific brother. His last investigation and critical discussion of the labours of other chemists was published in 1870 , "On Fermentation and the Origin of Muscular Force." In this he strenuously upholds his old theory of fermentation against Pasteur's explanation of the phenomena, and his vicws and arguments are as forcibly and clearly expressed as we find them in his early publications. The last of his hundreds of communications to the Annalen is a notice on the discovery of chloroform, published in March of last year, in which he calls attention to the fact that the discovery of this important substance is due to himself in $183 I$, and not to Soubeiran, as is generally supposed, although Liebig overlooked the small quantity of hydrogen (0.8 per cent.) which chloroform contains, and termed it a chloride of carbon.

As an author, Liebig is remarkable for the luridity and grace of his style. The best examples of this are to be found in his "Familiar Letters on Chemistry." His mode of popular treatment of a somewhat obscure subject is seen in the well-known chapter (xxiv.) in his "Familiar Letters," on "Spontaneous Combustion of the Human Body." He there goes step by step through all the better authenticated cases, shows the want of sufficient evidence in each case, points out the fallacies of the theories proposed to explain them, and concludes with proving, by the application of known physicaland chemical laws, that the supposed phenomena cannot possibly cccur. Looking once more back upon the labours of Liebig, we again come to the conclusion that the chief and characteristic glory of his life is the impulse which he gave to the study of our science and the personal influence which he exerted among his numerous and distinguished pupils.

The present short and imperfect sketch of the scientific bearings of a great life is not one in which personal qualities can be discussed; suffice it to say that though Liebig was an awkward adversary, he was a faithful friend, and always ready and anxious to assist deserving merit.

H. E. ROSCOE

\section{NOTES FROIT THE "CHALLENGER"}

$W^{E}$ left Santa Cruz on the evening of Friday, the $14^{\text {th }}$ of February. The weather was bright and pleasant with a light breeze-force equal to about 5 -from the northeast. Our course during the night lay nearly westward, and on the morning of the 17 th we sounded, about 75 miles from Teneriffe, and 2,620 miles from Sombrero Island, the nearest point in the Virgin group, in 1,891 fathoms, with a bottom of grey globigerina ooze, mixed with a little volcanic detritus. The average of two Miller-Casella thermometers gave a bottom temperature of $2^{\circ} \mathrm{C}$.

The slip water-bottle which was used by Dr. Meyer and Dr. Jacobsen in the German North-Sea Expedition of last summer was sent down to the bottom, and $\mathrm{Mr}$. Buchanan determined the specific gravity of the bottom water to be $1{ }^{\circ} 02584$ at a.temperature of $17^{\circ} 9 \mathrm{C}$., the specific gravity of surface water being $\mathrm{I}^{\circ} 02648$ at a temperature of $18^{\circ} .5 \mathrm{C}$.

All Sunday, the 16 th, we spent sailing with a light air from the northward, and by Monday morning we had made about 130 miles from our previous sounding. The dredge was put over at 5.15 A.M. with 2,700 fathoms rope, and a weight of 2 cwt. 300 fathoms before the dredge.

After steaming up to the dredge once or twice, haulingin was commenced at I.30 P.MI., and the dredge came up at 3.30 half full of compact yellowish ooze. The ooze was carefully sifted, but nothing was found in it with the exception of foraminifera, some otolites of fishes, some dead shells of pteropods, and one nutilated specimen of what appears to be a new Gephyrean. This animal has been examined by Dr. von Villemœs-Suhm, who finds that it shows a combination of the character of the Sipunculacea and the Priapulacea. As in the former group, the excretory orifice is near the mouth, in the anterior part of 